\title{
Varied clinical presentations of scar endometriosis: case reports
}

\author{
Nidhi Gupta, Farhat Mazhari*, Neha Varun, Reva Tripathi
}

Department of Obstetrics and Gynecology, Hamdard Institute of Medical Sciences and Research and HAHC Hospital, New Delhi, Delhi, India

Received: 09 May 2018

Accepted: 31 May 2018

*Correspondence:

Dr. Farhat Mazhari,

E-mail: farhatmazhari1987@gmail.com

Copyright: ( $)$ the author(s), publisher and licensee Medip Academy. This is an open-access article distributed under the terms of the Creative Commons Attribution Non-Commercial License, which permits unrestricted non-commercial use, distribution, and reproduction in any medium, provided the original work is properly cited.

\begin{abstract}
Endometriosis is the second most prevalent benign gynaecological condition, in reproductive age women, defined as the presence of functioning endometrial tissue outside uterine cavity. Scar endometriosis is a rare entity with an incidence of $0.3-1 \%$ among reproductive age women following obstetric and gynaecologic surgeries. Complaints of pain, tender mass, cyclical association with menstrual cycle is almost pathognomonic. Here we present two case reports of scar endometriosis recently encountered at our institute - caesarean scar endometriosis and episiotomy scar endometriosis. The quoted episiotomy scar endometriosis incidence is about $0.06-0.07 \%$ while that of caesarean scar endometriosis is $0.03-0.4 \%$.
\end{abstract}

Keywords: Caesarean section, Episiotomy, Scar endometriosis

\section{INTRODUCTION}

Endometriosis is the second most common gynaecological condition with a prevalence of $10-25 \%{ }^{1}$ It was first described by Carl Von Rokitansky in the year $1860 .^{2}$ Endometriosis is the ectopic implantation of endometrial tissue anywhere outside the uterine cavity. ${ }^{3}$ It may be endopelvic or extra-pelvic. The most common extrapelvic site is surgical scar area, majority being gynaecological surgeries. Scar endometriosis is a rare condition with an incidence of upto $1 \%$, following obstetric and gynaecologic surgeries. The quoted episiotomy scar endometriosis incidence is about 0.06 $0.07 \%$ while that of caesarean scar endometriosis is 0.03 $0.4 \% .4$ There are many theories regarding the pathogenesis and lots of controversy still exists. The pathogenesis behind scar endometriosis seems to be the autologous transplantation of viable endometrial tissues that implant at open episiotomy or caesarean wounds during vaginal delivery or caesarean sections. The diagnosis and complete treatment of scar endometriosis can be challenging. Wide surgical excision of the endometriotic tissue has been accepted as the main modality of treatment. We present two case reports of scar endometriosis, caesarean scar endometriosis and episiotomy scar endometriosis, which authors recently encountered in their center which were confirmed on histopathology study.

\section{CASE REPORTS}

\section{Case report 1: Episiotomy scar endometriosis}

A 30 year old woman, married for ten years, came to our Gynae OPD in May, 2017 with the complaints of pain and swelling of vulva on right side at the site of episiotomy scar. The pain and swelling started to appear about six months back, with increased intensity, during menstruation. Pain was initially cyclical but gradually it remained throughout her menses. Her last vaginal delivery with episiotomy was about five years back. Per abdomen examinations were otherwise normal. On local examination, there was a tense, tender nodule of about $2 \times 1 \mathrm{~cm}$ at the right mediolateral episiotomy site. Other pelvic examinations were normal. Her USG perineum 
showed a hypoechoic lesion with echogenic Internal septa in perineum on right side, suggestive of endometriotic deposit. The patient was operated under saddle block. A firm cystic mass of size $2 \times 1 \mathrm{~cm}$ was present along the episiotomy site near the fourchette. Wide surgical excision with $1 \mathrm{~cm}$ safety margin, was done around the scar site, removing the mass. The postoperative stay of the patient in hospital was uneventful.

The tissue was sent for histopathology where the reports showed presence of endometrial glands and stroma. The patient was followed after two months of the surgery and the surgery site showed normal healing with no tenderness or swelling. The patient was relieved of her symptoms during the menses.

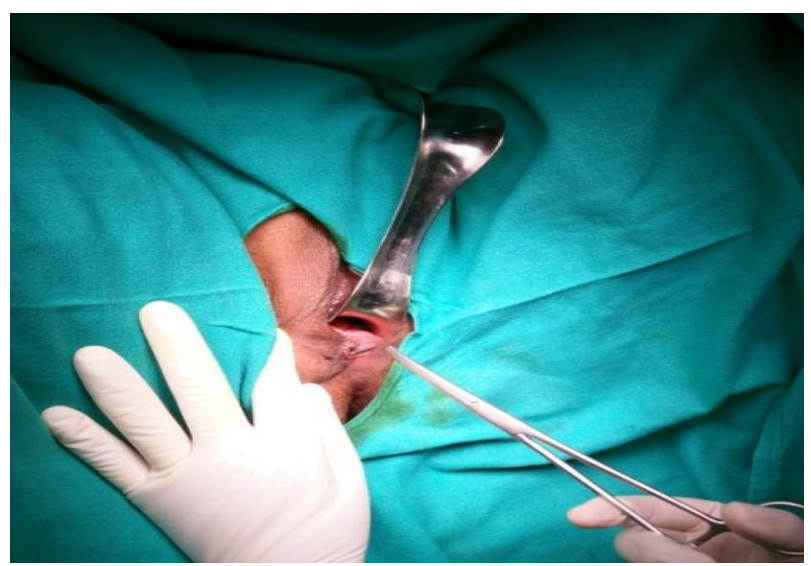

Figure 1: endometriosis site.

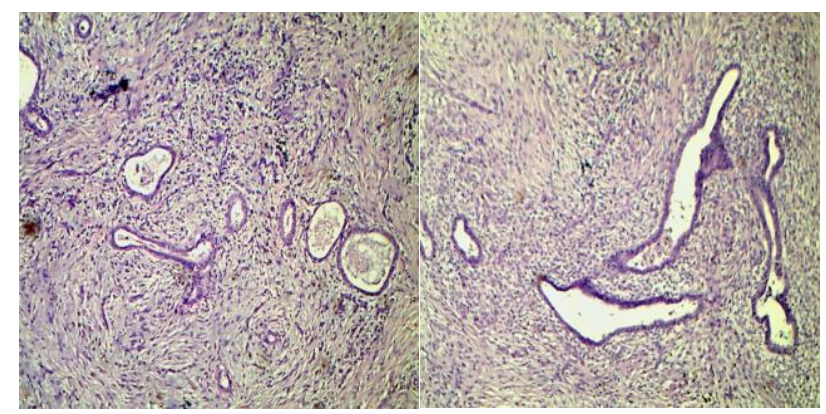

Figure 2: Endometriotic glands and stroma in the subcutaneous tissue.

\section{Case 2: Caesarean scar endometriosis}

A 27-year-old woman, P1L1, presented to our Gynae OPD in August 2017 with the complaints of pain and swelling on the caesarean scar for six months. She had her LSCS about four years back. The associated pain was significant during menses. Recently she had cyclical bleeding from this mass for 2 months, during menses. Examination revealed an approximately $4 \times 3 \mathrm{~cm}$ wide, tender, puckered, and immobile subcutaneous mass beneath the caesarean scar. Transabdominal ultrasound showed a $3.8 \times 2.3 \mathrm{~cm}$, oval-shaped heterogeneous mass with echogenic shadows in subcutaneous and deep soft tissue suggestive of scar endometriosis.

The patient was admitted and underwent surgical widen block excision of the scar endometriotic area, it had extended upto rectus sheath. The subsequent defects were repaired. The excised tissue was sent for histopathological examination which showed the presence of endometriotic glands and stroma. The postoperative stay of the patient was uneventful.

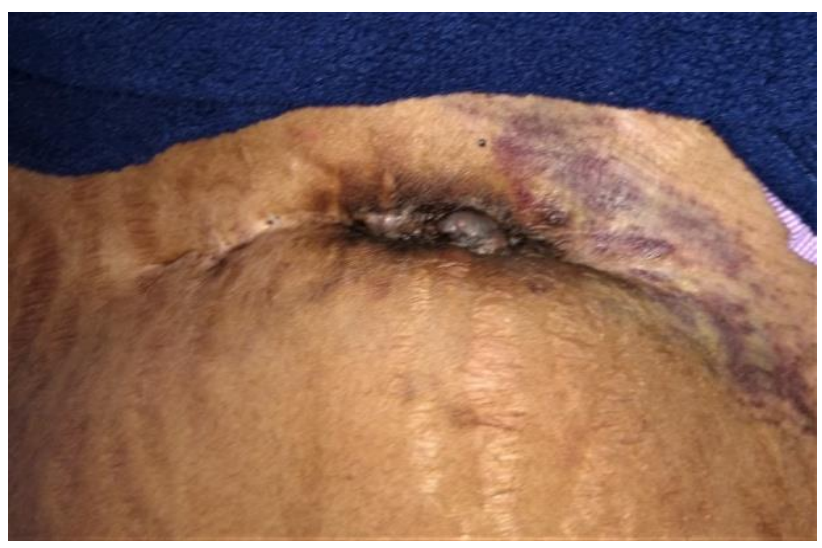

Figure 3: Caesarean scar endometriosis.

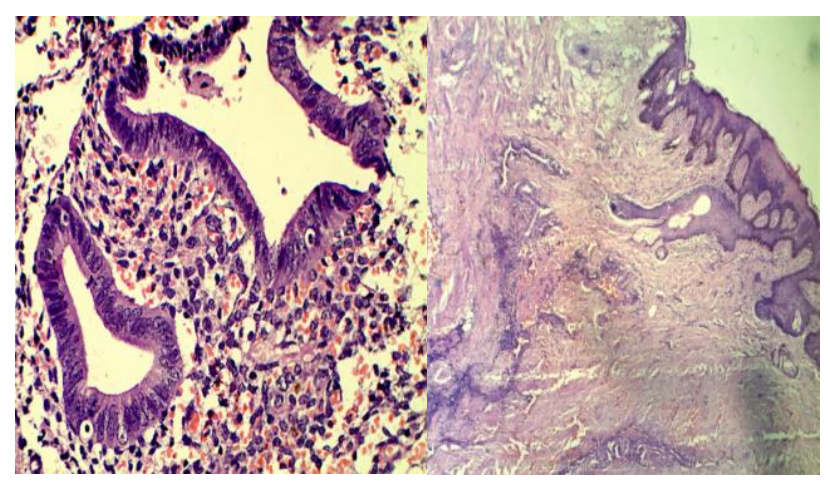

Figure 3: Dense chromatin nuclei with subnuclear vacuoles. Endometriotic glands and stroma in the subcutaneous tissue.

\section{DISCUSSION}

Endometriosis is the second most common gynaecologic disease in reproductive age group women. It was first described by Rokitansky in 1860.In 1896, Allen described for the first time extra-genital endometriosis and since then various cases have been reported. ${ }^{6}$ Endometriosis implants developing in the subcutaneous tissue of surgical scars occur most frequently after gynaecological and obstetrical procedures, including caesarean sections, hysterotomies, hysterectomies. Perineal scar endometriosis is a rare entity with incidence upto $1 \%$ affecting females at the episiotomy site following a previous vaginal delivery about 1-20 yrs back. According to Nominato et al, caesarean section is 
the most common surgical site of abdominal scar endometriosis. $^{7}$

Direct implantation of the vital endometrial stroma and glands to the open episiotomy wound during vaginal delivery, or manual uterine exploration or postpartum curettage; seems to be the pathogenic mechanism behind episiotomy scar endometriosis. Caesarean scar endometriosis is believed to be due to iatrogenic implantation of endometrial tissue in the abdominal fascia or subcutaneous tissue during caesarean sections. ${ }^{8}$ Patients usually present with a tender painful swelling at the scar site. The pain and swelling increases during menses.

A detailed medical history, examination findings and imaging methods lead to diagnosis. Histopathology is the gold standard for diagnosis which shows endometrial glands, stroma and hemosiderin laden macrophages. ${ }^{9}$ Treatment is wide surgical excision including healthy surrounding tissues to prevent recurrence. ${ }^{10}$ Medical management like OCP's, progesterones have been tried. ${ }^{11}$ Malignant transformation can occur in rare situations $(0.3-1 \%)$.

\section{CONCLUSION}

Scar endometriosis has now become even more important due to the increased number of obstetric surgical interventions. However, the high rate of diagnosis with a simple physical examination and medical history is an important advantage. Although scar endometriosis is a rare condition, but it leads to much morbidity of the patient, so an early diagnosis is necessary to avoid complications. Excision of lesions with a margin of safety is important, which should be $1 \mathrm{~cm}$, to prevent recurrence.

\section{Funding: No funding sources}

Conflict of interest: None declared

Ethical approval: Not required

\section{REFERENCES}

1. Vellido-Cotelo R, Muñoz-González JL, Oliver-Pérez MR, de la Hera-Lázaro C, Almansa-González C, Pérez-Sagaseta $\mathrm{C}$ et al. Endometriosis node in Gynaecologic scars: A study of 17 patients and the diagnostic considerations in clinical experience in tertiary care center. BMC Women's Health (2015) 15:13, available at http://www.biomedcentral.com/content/ pdf/s12905015-0170-9.pdf

2. Rokitansky C. Ober Uterusdrusen-Neubildung in Uterus-und Ovarial-Sarcomen. Z GeeselechAerzte Wien 16:577-81, 1860, cited by Collines.

3. American College of Obstetricians and Gynecologists. Practice bulletin no. 114: management of endometriosis. Obstet Gynecol. 2010;116(1):223-6.

4. Demir M, Yildiz A, Ocal I, Yetimalar MH, Kilic D, Yavasi O. Endometriosis in episiotomy scar: a case report. J Cases Obstet Gynecol. 2014;1(1):8-10.

5. Wolf Y, Haddad R, Werbin NY. Skornick, Kaplan O. Endometriosis in abdominal scars: adiagnosticpit fall. Am Surg. 1996;62(12)1042-44.

6. de Gauna BR, Rodriguez D, Cabré S, Callejo J. A case of endometriosis in episiotomy scar with anal sphincter involvement. Int J Clin Med. 2011;2(05):624.

7. Nominato NS, Prates LF, Lauar I, Morais J, Maia L, Geber S. Caesarean section greatly increases risk of scar endometriosis. Eur J Obstet Gynecol Rep Bio. 2010;152(1):83-5.

8. Sasson IE, Taylor HS. Stem cells and the pathogenesis of endometriosis. Ann N Y Acad Sci. 2008;1127(1):106-15.

9. Crum CP. The female genital tract. in Robbins Pathologic Basis of Disease, R. S. Cotran, V. Kumar, and V. Collins, Eds., Saunders, Philadelphia, Pa, USA, $6^{\text {th }}$ edition, 1999.

10. Gunes M, Kayikcioglu F, Ozturkoglu E, Haberal A. Incisional endometriosis after cesarean section, episiotomy and other gynecologic procedures. J Obstetr Gynaecol Res. 2005;31(5):471-5.

11. Rivlin ME, Das SK, Patel RB, Meeks GR. Leuprolide acetate in the management of cesarean scar endometriosis. Obstet Gynecol. 1995;85(5):8389.

12. Picod G, Boulanger L, Bounoua F, Leduc F, Duval G. Abdominal wall endometriosis after caesarean section: report of fifteen cases. Gynecol Obstet Fertilite. 2006;34(1):8-13.

Cite this article as: Gupta G, Mazhari F, Varun N, Tripathi R. Varied clinical presentations of scar endometriosis: case reports. Int J Reprod Contracept Obstet Gynecol 2018;7:2968-70. 